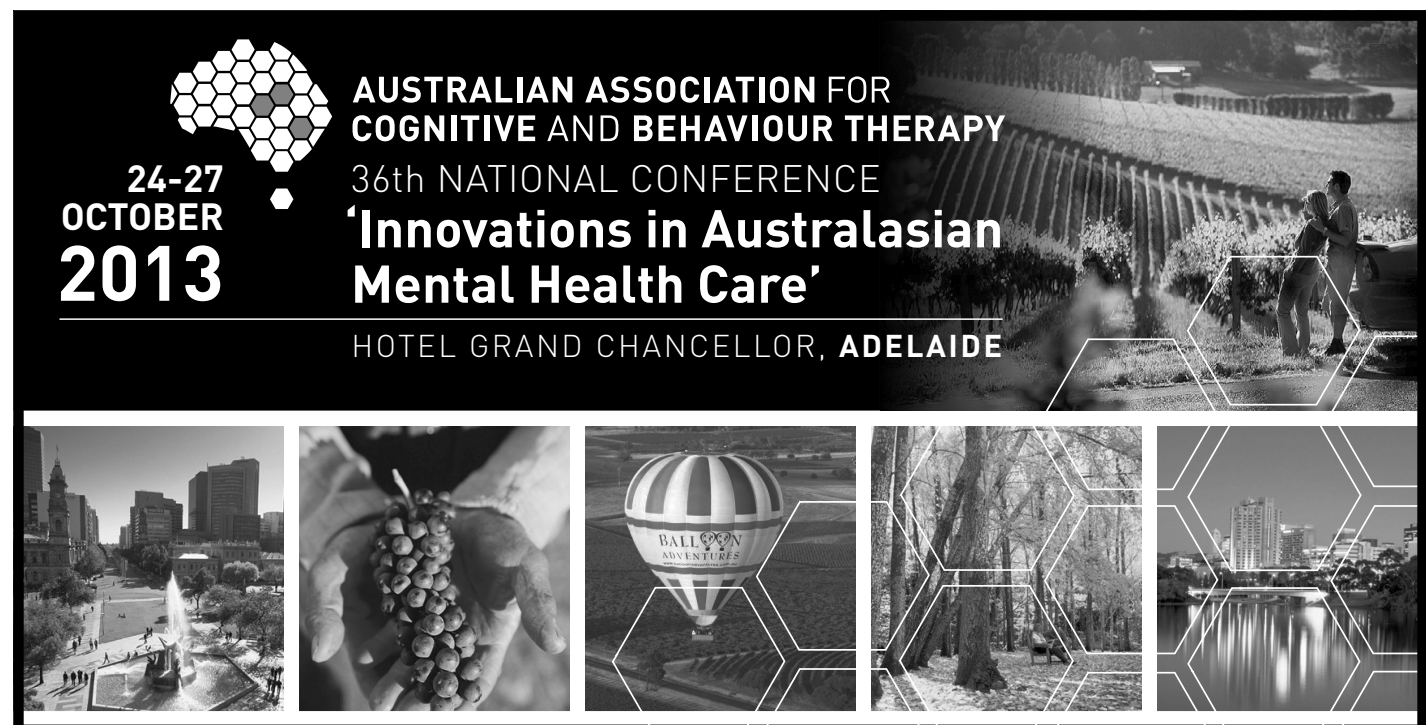

\title{
www.aacbt.org
}

\section{KEYNOTE SPEAKERS}

Tracey Wade

- Is CBT of Relevance to

Adolescents with Eating Disorders?

Louise Sharpe

- Novel Interventions in

Pain Management

\section{KEY DATES}

Call for Abstracts Closes

12 June 2013

Abstract notifications

22 July 2013

Early Bird Registration Closes

13 August 2013

\section{INVITED SPEAKERS}

Simon McCarthy-Jones

- Experience of Hearing Voices

Margaret Hartstone

- DBT for Borderline

Personality Disorder

Michael Gradisar

- Childhood Sleep Disorders

Junwen Chen

- Social Anxiety: Symptoms and Treatment in Western and

Eastern Countries
Ian Shochet

- The Resourceful Adolescent

Program and Depression

Prevention in Young People

Paul Rushton

- IPT for Depression

\section{WORKSHOP SPEAKERS}

\section{SATURDAY WORKSHOPS}

Paul Rushton

- IPT for Depression

Louise Sharpe

- CBT for Chronic Pain

Angela Davis \& Anna Farrall

- Working with Children with

Complex Needs land No

Diagnosis) Including Adopted

and Fostered Children and

Children with Sensory Issues

Michael Gradisar

- Treatment for Sleep Problems

in Infants, Toddlers, School Aged

Children and Teens

Susan Simpson

- Schema Therapy for Complex

Chronic Disorders/Personality

Disorders

\section{SUNDAY WORKSHOPS}

Carol Hunter

- Behaviour Management and Psychological Issues in

Older People

Maura Kenny

- Mindfulness Interventions

Ian Shochet

- The Resourceful Adolescent Program

Margaret Hartstone

- DBT Skills for Clients

Tracey Wade

- Treating Eating Disorders Successfully: Integrating Core Principles and Individualised Therapy

To find out more information and register visit

www.aacbt.org

\section{Conference Office}

WALDRONSMITH MANAGEMENT

$T+61396456311$

E cbtconferencedawsm.com.au 


\section{CAMBRIDGE JOURNALS}

\section{the Cognitive Behaviour Therapist}

Published for the British Association for Behavioural and Cognitive Psychotherapies (BABCP)

\section{Editor-in-Chief}

Pamela Myles, University of Reading, UK

$t C B T$ is an interdisciplinary, peer-reviewed journal aimed primarily at practitioners of cognitive behaviour therapy in the helping and teaching professions. It features papers covering clinical and professional issues, which contribute to the theory, practice and evolution of the cognitive and behavioural therapies. The journal publishes papers that describe new developments, are practice-focused, detail clinical interventions, research reports, case reports, practice audits, and reviews of clinical scales. The journal also publishes papers that have an education, training or supervision focus, or reviews of recently published literature.

\section{Price information}

is available at: http://journals.cambridge.org/cbt

\section{Free email alerts}

Keep up-to-date with new material - sign up at http://journals.cambridge.org/alerts

the Cognitive Behaviour Therapist is available online at: http://journals.cambridge.org/cbt

To subscribe contact Customer Services

\section{in Cambridge:}

Phone $+44(0) 1223326070$

Fax $+44(0) 1223325150$

Email journals@cambridge.org

\section{in New York:}

Phone +1 (845) 3537500

Fax +1 (845) 3534141

Email

subscriptions_newyork@cambridge.org 


\section{CAMBRIDGE JOURNALS}

\section{The Spanish Journal of Psychology}

Published on behalf of Universidad Complutense de Madrid and Colegio Oficial de Psicologos de Madrid

\section{Editor}

Javier Bandrés, Universidad Complutense de Madrid, Spain

The Spanish Journal of Psychology is published by the Universidad Complutense and the Colegio Oficial de Psicslogos de Madrid with the aim of promoting the international dissemination of relevant empirical research and theoretical and methodological proposals in the various areas of specialization within psychology.

\section{Americas:}

Phone +1 (845) 3537500

Fax +1 (845) 3534141

Email

subscriptions_newyork@cambridge.org

\section{Rest of world:}

Phone +44 (0)1223 326070

Fax +44 (0)1223 325150

Email journals@cambridge.org

\section{Free email alerts}

Keep up-to-date with new material - sign up at

journals.cambridge.org/sjp-alerts 


\section{CAMBRIDGE}

\section{JOURNALS}
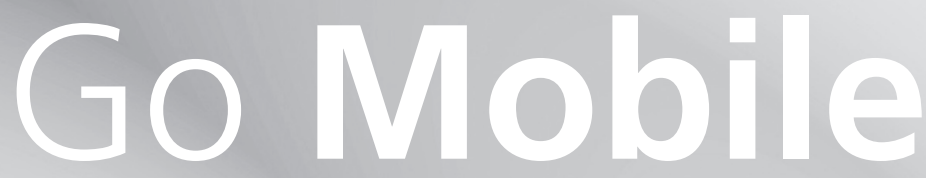

CJO Mobile $(\mathrm{CJOm})$ is a streamlined

Cambridge Journals Online (CJO)

for smartphones and other

small mobile devices

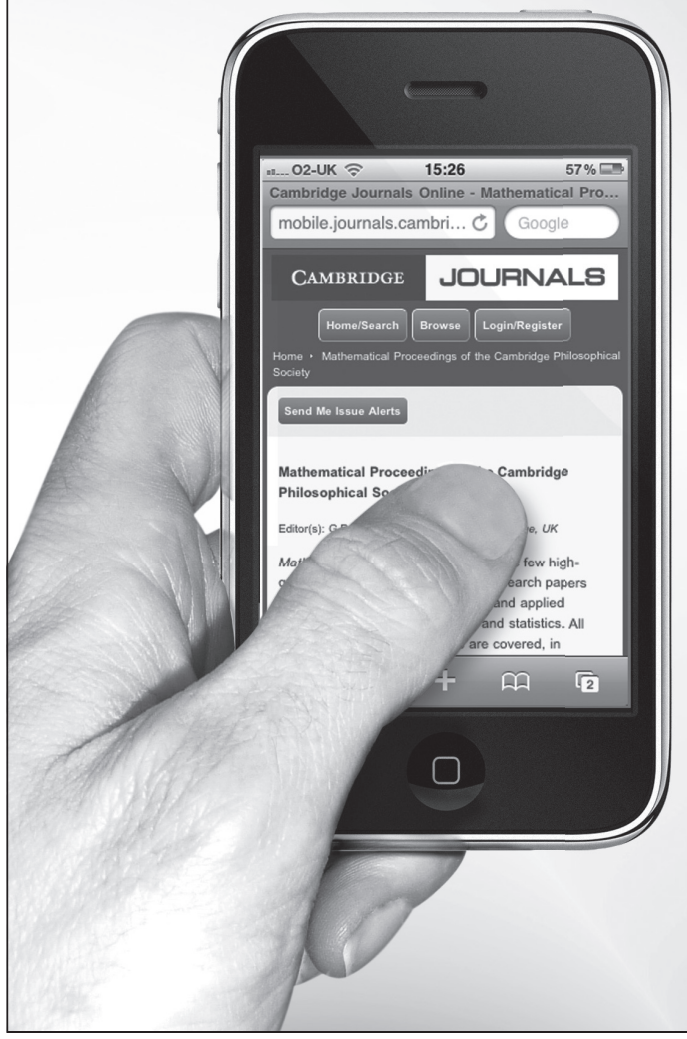

- Use CJOm to access all journal content including FirstView articles which are published online ahead of print

- Access quickly and easily thanks to simplified design and low resolution images

- Register for content alerts or save searches and articles they will be available on both CJO and CJOm

- Your device will be detected and automatically directed to CJOm via: journals.cambridge.org 


\section{Journal of \\ Smoking \\ Cessation}

\section{Founding Editor}

Renee Bittoun, Smoking Cessation Unit, University of Sydney, Australia

Journal of Smoking Cessation is the world's only publication devoted exclusively to the treatment of smoking cessation. The journal is targeted specifically to the area of smoking cessation at the "grass-roots" level, focusing on observational studies that have practical implications for those assisting smokers to quit. It is a high quality peer-reviewed publication with an international editorial board that has itself wide experience in the field of smoking cessation.

\section{Customer Services}

To subscribe contact

\section{in Cambridge:}

Phone +44 (0)1223 326070

Fax $+44(0) 1223325150$

Email journals@cambridge.org

\section{in New York:}

Phone +1 (845) 3537500

Fax +1 (845) 3534141

Email

subscriptions_newyork@cambridge.org

\section{Free email alerts}

Keep up-to-date with new material - sign up at journals.cambridge.org/jsc-alerts 


\section{Journal of Tropical Psychology}

\section{Editor}

Robert Morgan, University of Arkansas, USA

Associate and Managing Editor

Deborah Graham, James Cook University, Australia

Substantial psychological work is being done in tropical zone countries and regions. Journal of Tropical Psychology is specifically circum-global and unites the rapidly growing torrid climate-related nations around the earth in the development and sharing of their psychological discoveries. In addition to the geographical limits of past designated tropical countries, this rapidly expanding torrid or tropical zone could eventually and increasingly include all but the most polar regions. The journal's summary objectives are:

- To share the full range of psychological progress in the growing tropical climate regions

- To disseminate progress in adaptation to the global expansion tropical climates

- To develop an international network of psychologists working in these regions

To subscribe contact Customer Services

\section{in Cambridge:}

Phone +44 (0) 1223326070

$\mathrm{Fax}+44(0) 1223325150$

Email journals@cambridge.org

\section{in New York:}

Phone +1 (845) 3537500

$\mathrm{Fax}+1(845) 3534141$

Email

subscriptions_newyork@cambridge.org

\section{Free email alerts}

Keep up-to-date with new material - sign up at journals.cambridge.org/jtp-alerts 


\section{Journal of Pacific Rim Psychology}

\section{Editor}

Stuart Carr, Massey University, Aotearoa, New Zealand

Leo Marai, University of Papua New Guinea, Papua New Guinea

A quality peer-reviewed premium e-journal, the Journal of Pacific Rim Psychology has its history in the old South Pacific Journal of Psychology published between 1984 and 2005. The journal fills a void in contemporary psychology, with a focus on a region of the world that is extraordinarily vast, easily recognisable, and rich in cultural diversity and includes Oceania, Australasia, East Asia and the Western Seaboard of the Americas, and the 'hub' in the wheel — the Hawaiian Islands and other Pacific Island Nations. From climate change to disaster management and poverty reduction, the Pacific Rim region has its share of issues and potential solutions. With a focus on Indigenous and minority perspectives, the journal seeks to foster mutual capacity building in the research domain, and on questions of human development generally.

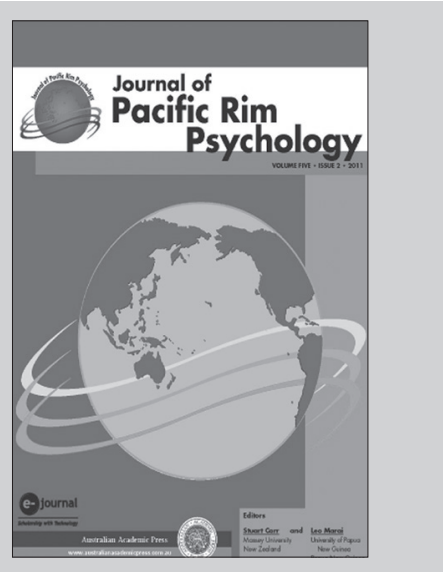

Journal of Pacific Rim Psychology is available online at: http://journals.cambridge.org/prp

To subscribe contact Customer Services

\section{in Cambridge:}

Phone +44 (0)1223 326070

Fax +44 (0)1223 325150

Email journals@cambridge.org

in New York:

Phone +1 (845) 3537500

Fax +1 (845) 3534141

Email

subscriptions_newyork@cambridge.org

\section{Free email alerts}

Keep up-to-date with new material - sign up at

journals.cambridge.org/prp-alerts 


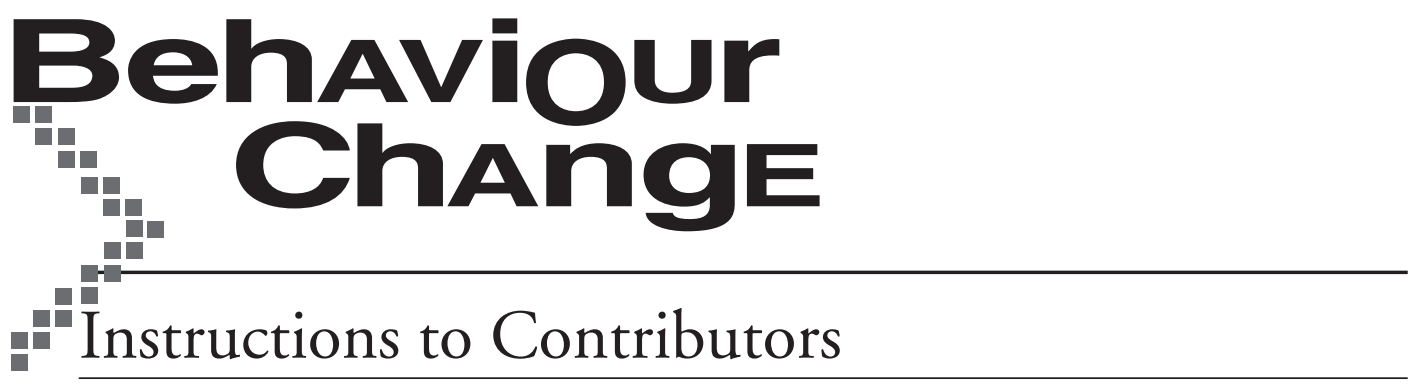

1. To be reviewed for possible publication in this journal all authors must follow the instructions below and submit their manuscript to:

https://www.australianacademicpress.com.au/cup_jsm/ All articles are refereed. Papers submitted to the journal must not previously have been published nor submitted for publication to any other journal.

2. Papers should be submitted via e-mail in Word or RTF format. Authors who wish to submit their paper in hard copy format may do so by arrangement with the editor.

3. Contributions should follow the format and style described in the Publication Manual of the American Psychological Association (5th ed.). Spelling and punctuation should conform to The Macquarie Dictionary (4th ed.). For matters of style not covered in these two publications the Style Manual for Authors, Editors and Printers (6th ed.) should be consulted.

4. Documents should be double-spaced with minimum margins of $20 \mathrm{~mm}$ on the left and $35 \mathrm{~mm}$ on the right. Uncommon abbreviations and acronyms should be explained. Do not use underlining except to indicate italics. Full stops should not be used in abbreviations or acronyms (e.g., NSW).

5. Use single quotation marks to introduce a word or phrase used as an ironic comment, as slang, or which has been coined. Use quotation marks the first time the word or phrase is used; do not use them again. Do not use quotation marks to introduce a technical or key term. Instead, italicise the term.

6. Front page: under the title of the article only the names and affiliations of the authors appear. Qualifications, present appointments, and postal and e-mail addresses should be given in a separate section on the front page labelled 'Address for correspondence'. A word count and suggested running head of no more than 50 characters including spaces should also be provided.

7. Do not use any footnotes. Endnotes should be kept to a minimum and listed at the end of the text under the centred heading 'Endnotes'. Acknowledgments should be placed at the end of the article with a separate heading.

8. Tables should be at the end of the manuscript, not in the main text. Their approximate positions in the text should be indicated by the words, 'Insert Table X here'. Horizontal and vertical lines should be used sparingly.

9. To ensure optimum quality, please follow these guidelines when submitting artwork via e-mail:

- Photographs, graphs and figures should be prepared to the correct size (max. width up to $120 \mathrm{~mm}$ ) and each one supplied as an individual file, separate to the manuscript Word file. Include placement instructions in the Word document, such as 'Insert Figure 1 here'.
- Figures created in Microsoft Word or Powerpoint need to be saved as PDFs.

- Figures created in a drawing program such as Adobe Illustrator, CorelDRAW, Freehand, Microsoft Publisher or similar should be saved as EPS (encapsulated postscript) files.

- Figures created in Photoshop or with other photographic software should be saved as line art (artwork that has only text and lines, no shades of grey or blocks of colour) with a minimum resolution of 600 dpi and in TIF format. Minimum resolution for scanned graphics is 300 dpi for halftone work (e.g., photographs) and $600 \mathrm{dpi}$ for line art, and these should also be in TIF format.

- Manuscripts that contain equations created with LaTeX or similar specialist software need to be supplied as a PDF file as well as a Microsoft Word document.

- Prior to sending artwork, the separate files of figures, graphs, illustrations, etc. should be printed by the author to test that the fonts have been embedded correctly and there is no distortion in the artwork (e.g., lines and fonts reproduce cleanly with no jagged lines or fuzzy edges), as any such faults cannot be corrected by the publisher.

- Preferred media for delivery: e-mail as attachments, Macintosh or PC floppy disk, Macintosh or PC Zip disk, CD-ROM. If your artwork does not meet these guidelines, it may be returned to you.

10. References and citations should follow the format and style described in the Publication Manual of the American Psychological Association (5th ed.). Examples of citations are:

The theory was first propounded in 1970 (Larsen, 1971).

Larsen (1971) was the first to propound the theory. Examples of references are:

Fisse, B. (1989). The proceeds of crime act: The rise of money laundering, offences and the fall of principle. Criminal Law Journal, 13, 5-23.

Zelinski, E.M., \& Gilewski, M.J. (1988). Memory for prose and aging: A meta-analysis. In M.L. Howe \& C.J. Brainerd (Eds.), Cognitive development in adulthood (pp. 133-158). New York: SpringerVerlag.

11. Authors are expected to check the accuracy of all references and citations in the manuscript before submission. 


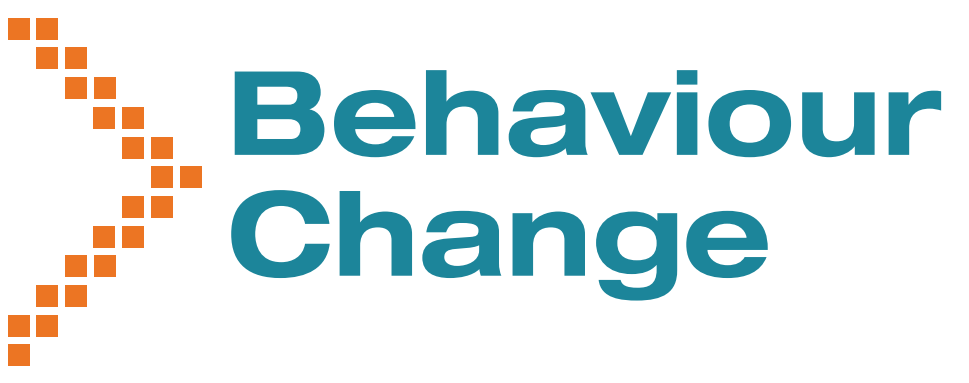

\section{Contents}

- Assessing Randomised Clinical Trials of Cognitive and Exposure Therapies for Gambling Disorders: A Systematic Review

David P. Smith, Kirsten I. Dunn, Peter W. Harvey, Malcolm W. Battersby, and Rene G. Pols

- Further Evidence That Repeated Checking Leads to Reduced Memory Confidence, Vividness and Detail: New Evidence That Repeated Object Exposure Also Results in Memory Distrust Meredith Medway, and Mairwen K. Jones

- Autobiographical Memory in Children and Adolescents With Acute Stress and Chronic Posttraumatic Stress Disorder Reginald D.V. Nixon, Shelly-Anne Ball, Jisca Sterk, Talitha Best, and Lisa Beatty

- The Common Fears and Their Origins Among Turkish Children and Adolescents Begüm Serim Yıldzz, Özgür Erdur-Baker, and Aslı Bugay

- Towards a Unified Worry Exposure Protocol for Generalised Anxiety Disorder: A Pilot Study Cameron Mclntosh, and Rocco Crino 